\title{
POTENSI KOMBUCHA DAUN TEH (Camellia sinensis) DAN DAUN KOPI ROBUSTA (Coffea robusta) SEBAGAI MINUMAN PROBIOTIK
}

\section{Potential of Kombucha Tea Leaves (Camellia sinensis) and Robusta Coffee Leaves (Coffea robusta) as Probiotic Beverage}

\author{
Elok Zubaidah, Kiki Fibrianto, Soviandini Dwiki Kartikaputri \\ Jurusan Teknologi Hasil Pertanian, Fakultas Teknologi Pertanian, Universitas Brawijaya \\ Jl. Veteran - Malang 65145 \\ *Email: soviandinidwiki@gmail.com
}

\begin{abstract}
Kombucha is a plant-based fermented beverage that contains probiotic bacteria such as lactic acid bacteria ( $L A B)$. This research was conducted to prove the potential of probiotics in $L A B$ isolates of kombucha tea leaves and robusta coffee leaves with various concentrations. This research used a completely randomized design (CRD). The variables tested were the measurement of total lactic acid bacteria, total acid, and probiotic characterization of $L A B$ isolates ( $L A B$ resistance to low $\mathrm{pH}$ and bile salts, and antibacterial activity test). The results were analyzed and discussed using ANOVA with a significance level of $P<0.05$ only for total acid and descriptive analysis on microbiological response. The best probiotic potency was selected using the multiple attribute method. The results showed that LAB isolates from kombucha tea leaves and robusta coffee leaves with various concentrations had resistance to $\mathrm{pH} 2$ and $\mathrm{pH} 3$, resistance to bile salts 3\%, and antibacterial activity against Staphylococcus aureus and Escherichia coli bacteria. The LAB isolate of kombucha robusta coffee leaves at a concentration of $0.6 \%$ has the best probiotic potential.
\end{abstract}

Keywords: fermentation, kombucha, probiotic, robusta coffee leaves, tea leaves

\begin{abstract}
ABSTRAK
Kombucha merupakan minuman fermentasi berbasis tanaman yang mengandung bakteri probiotik seperti bakteri asam laktat (BAL). Penelitian ini dilakukan untuk membuktikan potensi probiotik pada isolat BAL kombucha daun teh dan daun kopi robusta dengan berbagai konsentrasi. Penelitian laboratorium menggunakan rancangan acak lengkap (RAL). Variabel yang diuji adalah pengukuran total bakteri asam laktat, total asam, ketahanan BAL terhadap $\mathrm{pH}$ rendah dan garam empedu, serta uji aktivitas antibakteri. Hasil penelitian dianalisa dan dibahas menggunakan ANOVA dengan signifikansi $P<0.05$ hanya untuk total asam dan analisa deskriptif pada respons mikrobiologis. Potensi probiotik terbaik dipilih menggunakan metode multiple attribute. Hasil penelitian menunjukkan bahwa isolat BAL dari kombucha daun teh dan daun kopi robusta dengan berbagai konsentrasi memiliki ketahanan terhadap $\mathrm{pH} 2$ dan $\mathrm{pH} 3$, ketahanan terhadap garam empedu 3\%, serta aktivitas antibakteri terhadap bakteri Staphylococcus aureus dan Escherichia coli. Isolat BAL kombucha daun kopi robusta pada konsentrasi $0,6 \%$ mempunyai potensi probiotik terbaik.
\end{abstract}

Kata Kunci: daun kopi robusta, daun teh, fermentasi, kombucha, probiotik 


\section{PENDAHULUAN}

\begin{tabular}{llll}
\multicolumn{1}{c}{ Dewasa } & ini, & penderita & penyakit \\
degeneratif & seperti & penyakit & jantung, \\
hipertensi, & obesitas, serta & diabetes
\end{tabular} mengalami peningkatan yang cukup pesat. Salah satu pemicu penyakit degeneratif adalah adanya ketidak-seimbangan mikroflora yang ada di dalam usus yang dapat dijaga dengan mengonsumsi pangan fungsional fermentasi seperti kombucha (Azka et al. 2018). Kombucha merupakan produk fermentasi teh oleh Symbiotic Culture of Yeast and Bacteria (SCOBY). Yeast yang terdapat dalam SCOBY adalah Saccharomyces sp., Zygosaccharomyces sp., Dekkera/Brettanomyces sp., dan Pichia $s p$., sedangkan bakteri yang terdapat dalam SCOBY adalah Acetobacter xylinus, Acetobacter xylinum, Acetobacter aceti, Gluconobacter xylinus, Gluconacetobacter xylinus, Lactobacillus sp., Leuconostoc sp., Lactococcus sp., dan Oenococcus $s p$ (Laureys et al. 2020). Kombucha mengandung senyawa polifenol, asam organik, vitamin, asam amino, dan berbagai mikronutrien yang terbentuk selama proses fermentasi. Beberapa penelitian membuktikan efek kombucha terhadap kesehatan antara lain adalah sebagai antibakteri terhadap bakteri patogen, mengatasi masalah pencernaan, diabetes, hiperkolesterolemia, tekanan darah tinggi, serta meningkatkan sistem pertahanan tubuh (Hrnjez et al. 2014).

Kombucha biasa terbuat dari ekstrak daun teh (Camellia sinensis). Daun teh memiliki kandungan alkaloid, flavonoid, steroid, tannin, saponin, dan triterpenoid (Noriko 2013). Teh hitam dan gula putih merupakan substrat yang baik dalam pembuatan kombucha. Pembuatan kombucha juga dapat memanfaatkan jenis daun lain seperti daun kopi robusta. Daun kopi mengandung senyawa alkaloida, saponin, flavonoida dan polifenol (Fibrianto et al. 2020). Kombucha mengandung berbagai macam mikroorganisme yang tergolong sebagai probiotik.

Probiotik merupakan mikroorganisme hidup yang dapat dikonsumsi dalam jumlah tertentu yang mampu memberikan manfaat bagi kesehatan. Probiotik mampu memberikan manfaat terhadap kesehatan antara lain meningkatkan respons imun terhadap infeksi usus, menurunkan tekanan darah, menurunkan kadar kolesterol serum, mengurangi lactose intolerance, dan mencegah terjadinya tumor dan kanker kolon (Kumar et al. 2012). Salah satu bakteri yang tergolong sebagai probiotik yaitu bakteri asam laktat (BAL). BAL merupakan bakteri yang mampu menghasilkan asam laktat melalui proses fermentasi baik secara homofermentatif maupun heterofermentatif. BAL memiliki tingkat ketahanan hidup yang tinggi karena BAL memiliki mekanisme untuk bertahan hidup terhadap asam lambung dan garam empedu serta memiliki aktivitas antibakteri terhadap bakteri patogen (König et al. 2017).

Tujuan penelitian ini adalah untuk membuktikan adanya potensi probiotik pada isolat BAL dari kombucha daun teh dan daun kopi robusta. Isolat BAL yang didapat akan diuji potensi probiotiknya melalui uji total BAL, total asam, ketahanan bakteri terhadap $\mathrm{pH}$ rendah, ketahanan bakteri terhadap bile salt, serta aktivitas antibakteri terhadap bakteri gram positif dan bakteri gram negatif.

\section{BAHAN DAN METODE}

\section{Tempat dan waktu penelitian}

Penelitian dilakukan di Laboratorium Mikrobiologi Pangan dan Laboratorium Biokimia dan Kimia Pangan, Jurusan Teknologi Hasil Pertanian Universitas Brawijaya. Penelitian ini berlangsung selama 5 bulan dimulai pada bulan AgustusDesember 2019.

\section{Alat dan bahan}

Alat yang digunakan pada pembuatan kombucha adalah jar kaca, panci berenamel, pengaduk kaca, timbangan analitik Scout Pro, gelas ukur merek Pyrex Iwaki, spatula, tea bag, dan serbet kertas. Alat yang digunakan untuk analisa adalah cawan petri Pyrex Iwaki dan Herma, tabung reaksi Pyrex Iwaki, gelas ukur Pyrex Iwaki, bunsen, spreader, pinset, autoklaf GEA LS 100-LJ, Hettich Mikro 200-200R centrifugator, tabung valcon, colony counter BZG 30, inkubator Binder BD/ 53, mikropipet Gilson, microtip Onemed, dan LW Scientific TM 2000 vortex.

Bahan yang digunakan pada pembuatan kombucha adalah daun kopi robusta (Coffea robusta), daun teh hitam Tong Tji, gula pasir Gulaku, starterkombucha 
yang didapatkan dari Indokombucha, dan air mineral Aqua. Daun kopi robusta yang digunakan didapatkan dari Dusun Sanggrahan, RT 07/RW 01, Sanggrahan, Kecamatan Ampelgading, Tirto Yudo, Kabupaten Malang, Jawa Timur. Daun kopi robusta dilayukan terlebih dahulu kemudian dipotong dan dibiarkan selama 12 jam. Setelah itu, daun kopi robusta dikeringkan dengan menggunakan oven dengan suhu 70 C selama 5-6 jam.

Bahan yang digunakan untuk proses analisa adalah asam klorida $(\mathrm{HCl}) 5 \%$, alkohol, aquades yang didapatkan dari $\mathrm{CV}$. Duta Jaya, $\mathrm{pH}$ stripe meter Jonson, garam empedu (Bile Salt L55) yang diperoleh dari Laboratorium Mikrobiologi Fakultas Kedokteran Universitas Brawijaya, kertas cakram antibakteri Macherey-Nagel, media Nutrient Broth (NB) Merck, media Nutrient Agar (NA) Merck, media de Man, Rogosa, and Sharpe Agar (MRSA) Merck, media de Man, Rogosa, and Sharpe Broth (MRSB) Merck, larutan pepton, serta isolat bakteri Staphylococcus aureus dan isolat Escherichia coli yang didapatkan dari Laboratorium Mikrobiologi Pangan, Fakultas Teknologi Pertanian, Universitas Brawijaya.

\section{Pembuatan kombucha}

Pada pembuatan kombucha, daun teh dan daun kopi ditimbang dengan variasi konsentrasi yaitu $0,2 \%, 0,4 \%$, dan $0,6 \%(b / v)$. Setelah itu, daun teh dan daun kopi robusta diseduh dan ditambah gula pasir sebanyak $10 \%$ (b/v). Selanjutnya, seduhan teh hitam dan daun kopi didinginkan pada suhu $25 \pm 2$ C. Starter kombucha berupa air SCOBY yang mengandung yeast, bakteri asam asetat, dan bakteri asam laktat, ditambahkan pada seduhan teh hitam dan daun kopi yang sudah dingin sebanyak $10 \%(\mathrm{v} / \mathrm{v})$ kemudian jar ditutup dengan serbet kertas dan diletakkan pada ruangan yang tidak terkena sinar matahari secara langsung dan dalam suhu ruang (25 $\left.\pm 2{ }^{\circ} \mathrm{C}\right)$ selama 10 hari. Pengambilan sampel untuk analisa dilakukan pada inkubasi hari ke-10 (modifikasi Villarreal-Soto et al. 2018).

\section{Analisa total BAL}

Pengujian total BAL dilakukan dengan menggunakan metode Total Plate Count (TPC) dimana sampel kombucha diambil sebanyak $1 \mathrm{~mL}$ kemudian dimasukkan ke dalam $9 \mathrm{~mL}$ larutan pepton steril dan diencerkan hingga $10^{-4}$. Pada 3 pengenceran terakhir diinokulasikan sebanyak $1000 \mu \mathrm{L}$ pada media MRSA steril dengan metode pour plate dan diinkubasi selama 48 jam pada suhu $37^{\circ} \mathrm{C}$. Koloni yang terbentuk dihitung menggunakan colony counter (modifikasi Wang et al. 2016).

\section{Analisa total asam}

Penentuan total asam dilakukan dengan metode titrasi. Sampel kombucha diambil sebanyak $10 \mathrm{~g}$ dan dimasukkan dalam labu ukur $100 \mathrm{~mL}$ kemudian ditambahkan aquades hingga tanda batas dan dihomogenkan. Selanjutnya diambil 50 $\mathrm{mL}$ dan dimasukkan dalam erlenmeyer dan ditambahkan indikator fenolftalein 1\% sebanyak 2-3 tetes kemudian dititrasi dengan menggunakan $\mathrm{NaOH}$ hingga terjadi perubahan warna (modifikasi Sudarmaji 1997).

\section{Analisa ketahanan terhadap $\mathrm{pH}$ rendah}

Pengujian ketahahan BAL terhadap $\mathrm{pH}$ rendah dilakukan dengan mengisolasi BAL dari masing-masing kombucha pada media MRSB yang ditambahkan $\mathrm{HCl} 5 \%$ hingga mencapai $\mathrm{pH} 2$ dan 3. Selanjutnya isolat dalam MRSB diinkubasi selama 24 jam pada suhu $37^{\circ} \mathrm{C}$. Isolat dalam MRSB diencerkan hingga pengenceran $10^{-4}$ menggunakan larutan pepton. Tiga pengenceran terakhir diinokulasikan sebanyak $1000 \mu \mathrm{L}$ pada media MRSA steril dengan menggunakan metode pour plate dan diinkubasi selama 48 jam pada suhu $37^{\circ} \mathrm{C}$. Koloni yang terbentuk dihitung menggunakan colony counter (modifikasi Puspawati dan Arihantana 2016).

\section{Analisa ketahanan terhadap garam empedu}

Pengujian ketahanan BAL terhadap garam empedu dilakukan dengan mengisolasi BAL pada media MRSB yang ditambahkan dengan garam empedu 3\% $(\mathrm{b} / \mathrm{v})$. Isolat dalam MRSB diinkubasi selama 24 jam pada suhu $37^{\circ} \mathrm{C}$. Isolat dalam MRSB diencerkan hingga pengenceran $10^{-4}$ menggunakan larutan pepton. Tiga pengenceran terakhir diinokulasikan sebanyak $1000 \mu \mathrm{L}$ pada media MRSA steril dengan menggunakan metode pour plate. Hasil inokulasi diinkubasi selama 48 jam pada suhu $37^{\circ} \mathrm{C}$. Koloni yang terbentuk 
dihitung menggunakan colony counter (modifikasi Saguibo et al. 2019).

\section{Analisa aktivitas antibakteri}

Pengujian aktivitas antibakteri dilakukan menggunakan metode difusi cakram. BAL kombucha diisolasi menggunakan media MRSB steril dan diinkubasi selama 48 jam pada suhu $37^{\circ} \mathrm{C}$. S.aures dan E. coli yang tumbuh dalam NB selama 24 jam diambil sebanyak $100 \mu \mathrm{L}$ dan diinokulasikan dengan metode spread plate. Isolat BAL dalam MRSB disentrifugasi selama 15 menit dengan kecepatan 6.000 rpm. Supernatan yang didapat diambil sebanyak $20 \mu \mathrm{L}$ dan diteteskan pada kertas cakram steril. Kertas cakram diletakkan diatas permukaan NA yang sudah berisi kultur S.aures dan E. coli dan diinkubasi selama 3 jam pada suhu $37^{\circ} \mathrm{C}$ (modifikasi Azka et al. 2018).

\section{Analisa data}

Data hasil pengamatan yang diperoleh dianalisa menggunakan ANOVA hanya untuk total asam, sedangkan pada respons mikrobiologi analisa dilakukan secara deskriptif. Isolat BAL dengan potensi probiotik terbaik dipilih menggunakan metode multiple attribute (Zeleny 1982).

\section{HASIL DAN PEMBAHASAN}

\section{Karakteristik bahan baku}

Pada penelitian ini, bahan baku yang digunakan adalah seduhan dari daun teh hitam dengan merek Tong Tji dan daun kopi robusta yang berasal dari Kecamatan Ampelgading, Kabupaten Malang, dan dilakukan penambahan gula pasir sebanyak $10 \%$. Karakteristik bahan baku kombucha daun teh dan daun kopi robusta dapat dilihat pada Tabel 1 dan Gambar 1.

Pada Tabel 1 tampak bahwa total gula pada seduhan daun teh lebih tinggi dibandingkan dengan seduhan daun kopi robusta. Total gula dipengaruhi oleh penambahan gula pasir sebanyak $10 \%$ dan kandungan gula pada daun teh dan daun kopi robusta sendiri. Total asam pada seduhan daun kopi robusta lebih tinggi dibandingkan dengan daun teh. Total asam dipengaruhi proses oksidasi saat pengolahan daun teh dan daun kopi robusta menyebabkan penurunan total asam (Kusuma dan Fibrianto 2018). Kadar tanin pada seduhan dauh teh lebih tinggi dibandingkan seduhan daun kopi robusta. Kadar tanin dipengaruhi proses oksidasi yang mengubah senyawa tanin menjadi senyawa-senyawa turunan seperti thearubigin dan theaflavin (Kusuma dan Fibrianto 2018). Total fenol pada daun teh

Tabel 1. Karakteristik bahan baku kombucha berbasis daun teh dan daun kopi robusta

\begin{tabular}{lcccc}
\hline Jenis Seduhan & $\begin{array}{c}\text { Total Gula } \\
(\%)\end{array}$ & $\begin{array}{c}\text { Total Asam } \\
(\%)\end{array}$ & $\begin{array}{c}\text { Kadar Tanin } \\
(\%)\end{array}$ & $\begin{array}{c}\text { Total Fenol } \\
\left(\mu \mathrm{GAE} \mathrm{mL} \mathrm{mL}^{-1}\right)\end{array}$ \\
\hline Daun Teh & $12,35 \pm 0,09$ & $0,18 \pm 0,02$ & $0,24 \pm 0,01$ & $263,50 \pm 2,13$ \\
Daun Kopi Robusta & $11,87 \pm 0,12$ & $0,38 \pm 0,03$ & $0,15 \pm 0,02$ & $197,82 \pm 1,72$ \\
\hline
\end{tabular}

Keterangan: Hasil analisis merupakan nilai rerata 3 kali ulangan dengan \pm standar deviasi

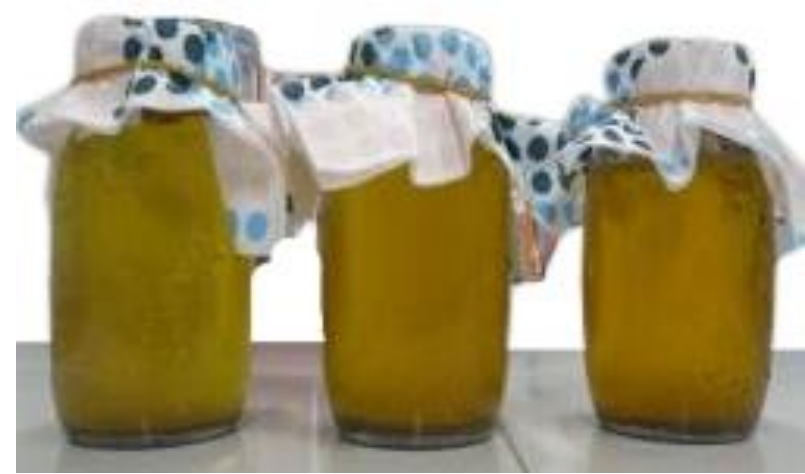

(a)

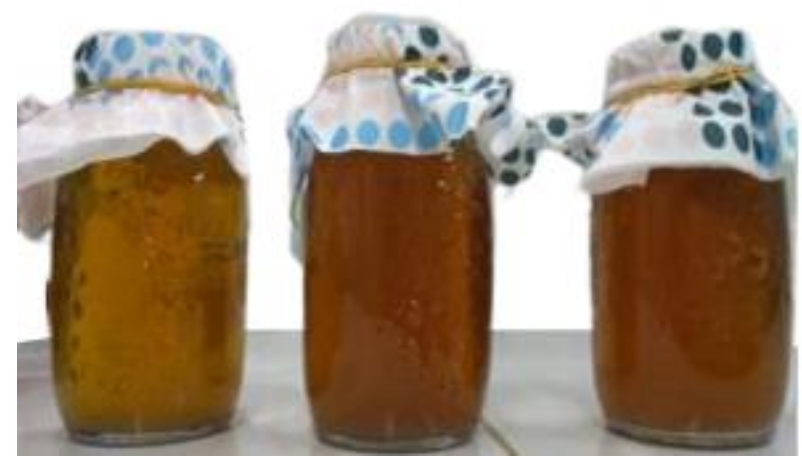

(b)

Gambar 1. Kombucha daun kopi robusta (a), kombucha daun teh (b) 
lebih tinggi dibandingkan dengan daun kopi robusta. Total fenol dipengaruhi proses pelayuan dan pengeringan yang menyebabkan kerusakan zat aktif dan oksidasi senyawa fenolik yang dikatalisasi oleh enzim oksidase (Novita et al. 2018).

\section{Total bakteri asam laktat}

Berdasarkan rerata hasil yang didapatkan, total BAL berada pada rentangan $5,9 \times 10^{3}$ hingga $3,1 \times 10^{4}$ (Gambar 2). Terlihat bahwa total BAL mengalami perubahan seiring dengan adanya variasi jenis daun dan konsentrasi. Total BAL tertinggi ada pada kombucha berbasis daun kopi robusta $0,6 \%$. Secara keseluruhan total BAL pada kombucha daun kopi robusta lebih tinggi dibandingkan dengan kombucha daun teh. Hal ini diduga disebabkan karena kandungan kafein pada daun teh lebih tinggi dibandingkan pada daun kopi robusta, dimana kafein memiliki sifat antimikroba, sehingga mampu menghambat pertumbuhan BAL (Nur dan Indrayati 2018). Selain itu, total gula pada bahan baku kombucha berbasis daun teh lebih tinggi dibandingkan dengan bahan baku kombucha daun kopi robusta dimana BAL akan memanfaatkan glukosa untuk menghasilkan asam laktat melalui siklus Krebs dan menghasilkan hasil samping seperti etanol dan karbondioksida. Semakin tinggi kadar glukosa maka proses fermentasi juga semakin cepat sehingga produksi etanol juga akan meningkat dan membunuh BAL pada konsentrasi tertentu (Pinto et al. 2019). Total fenol pada bahan baku kombucha teh lebih tinggi dibandingkan dengan kombucha daun kopi robusta, dimana total fenol yang tinggi dapat menghambat pertumbuhan BAL (Kusuma dan Fibrianto 2018).

Symbotic of Yeast and Bacteria (SCOBY) mengandung banyak spesies yeast dan bakteri yang berperan dalam proses fermentasi kombucha. Yeast pada kombucha didominasi oleh Saccharomyces cerevisiae. Selain itu, Zygosaccharomyces parabaili, $Z$. bailii, Z. kombuchaensis, Dekkera bruxellensis, Hanseniaspora valbyensis. $H$. vineae, Torulaspora delbrueckii, serta Blastobotrys adeninivorans juga berperan dalam proses fermentasi kombucha. Yeast yang terdapat pada SCOBY mampu menghasilkan enzim invertase yang mengkatalisasi hidrolisis sukrosa menjadi fruktosa, glukosa, dan etanol. Bakteri yang berperan dalam proses fermentasi kombucha adalah bakteri asam asetat seperti Acetobacter spp., A. aceti, Gluconobacter spp., G. europaeus, Komagataeibacter spp., $K$. saccharivorans (Sengun dan Kirmizigul 2020). Bakteri asam asetat menggunakan glukosa hasil perombakan sukrosa oleh yeast untuk memproduksi asam glukonat dan etanol yang kemudian diubah kembali menjadi asam asetat. Selain bakteri asam asetat, bakteri asam laktat juga berperan dalam proses fermentasi kombucha. Lactobacillus spp., Limosilactobacillus fermentum, Lactococcus spp., Leuconostoc sp., Enterococcus sp., dan Allobaculum sp. merombak glukosa secara homofermentatif atau heterofermentatif. Pada homofermentatif, bakteri asam laktat merombak glukosa melalui jalur Embden-

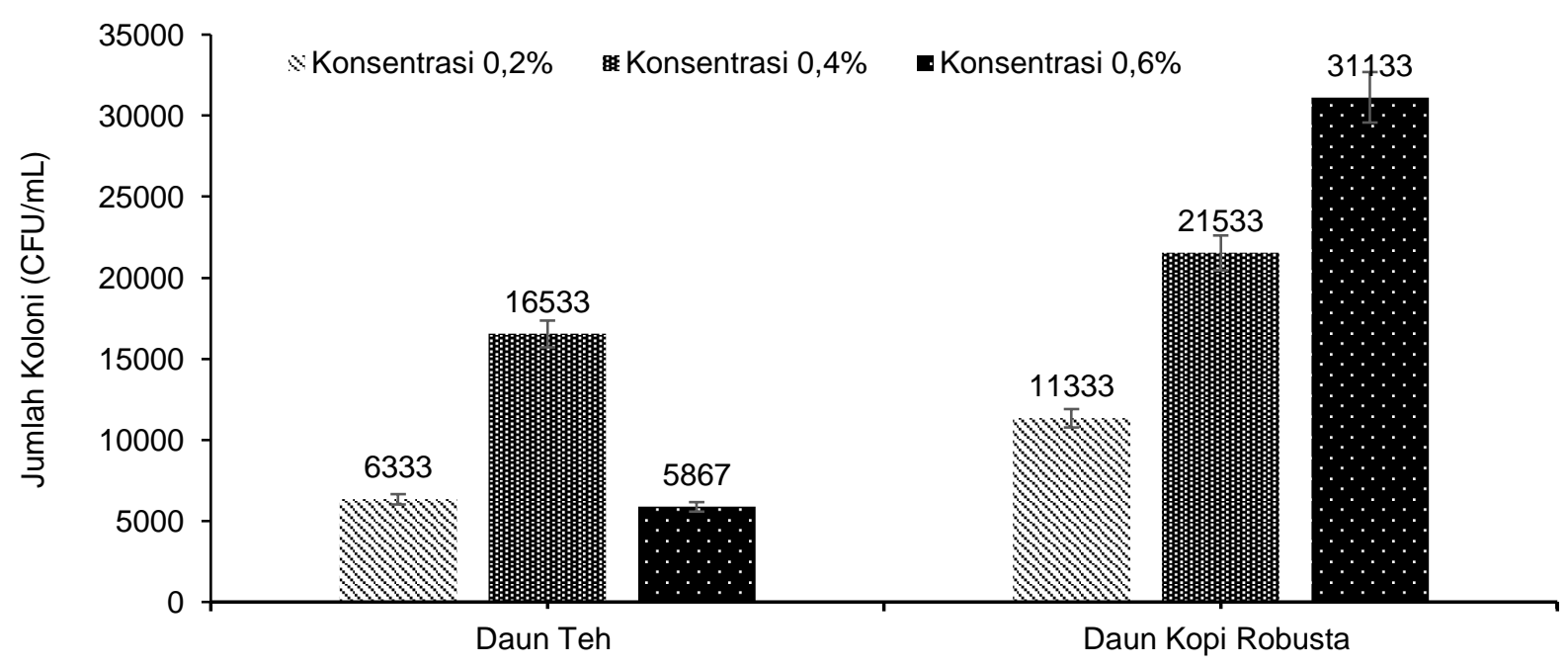

Gambar 2. Total bakteri asam laktat pada kombucha berbasis daun teh dan daun kopi robusta dengan variasi konsentrasi setelah fermentasi selama 10 hari 
Meyerhof-Parnas (EMP) menghasilkan asam laktat. Sedangkan pada heterofermentatif, bakteri asam laktat merombak glukosa melalui jalur pentosa fosfat dan menghasilkan asam laktat, karbondioksida, dan etanol (Laureys et al. 2020).

\section{Total asam}

Analisa total asam pada penelitian ini dilakukan pada hari ke-0 dan ke-10. Berdasarkan analisa yang dilakukan lama fermentasi memberikan perubahan terhadap rerata total asam dimana pada fermentasi kombucha hari ke-10 rerata total asam mencapai $1 \%$ hingga $1,52 \%$ pada kombucha berbasis daun teh dan 1,02\% hingga 1,60\% pada kombucha berbasis daun kopi robusta (Gambar 3). Tampak bahwa terjadi peningkatan total asam selama proses fermentasi seiring dengan adanya peningkatan konsentrasi. Total asam tertinggi ada pada kombucha berbasis daun kopi robusta $0,6 \%$. Secara keseluruhan, total asam pada kombucha daun teh lebih rendah apabila dibandingkan dengan kombucha daun kopi robusta. Berdasarkan analisa ragam, variasi konsentrasi tidak memberikan pengaruh nyata terhadap peningkatan total asam, sedangkan variasi jenis memberikan perbedaan yang nyata $(p<0,05)$ terhadap peningkatan total asam pada kombucha berbasis daun teh dan daun kopi yang dapat dilihat pada Tabel 2 .

Tabel 2 menunjukkan bahwa peningkatan total asam pada kombucha daun kopi robusta lebih rendah dibandingkan dengan peningkatan total asam pada kombucha daun teh. Hal ini diduga karena total gula yang ada pada bahan baku kombucha daun teh lebih tinggi dibandingkan kombucha daun kopi robusta. Sukrosa akan dipecah menjadi glukosa dan fruktosa oleh khamir, kemudian glukosa akan dimanfaatkan oleh bakteri untuk membentuk senyawa asam-asam organik seperti asam asetat, asam laktat, dan asam glukoronat serta etanol (Kusuma dan Fibrianto 2018). Menurut Shang et al. (2019), bakteri asam laktat akan mengubah glukosa menjadi asam laktat dan hasil samping seperti karbondioksida dan etanol.

\section{Ketahanan terhadap $\mathrm{pH}$ rendah}

Berdasarkan hasil yang didapatkan, jumlah koloni pada pH 3 mencapai 1,5 × 104
CFU $\mathrm{mL}^{-1}$ hingga $7,0 \times 10^{4} \mathrm{CFU} \mathrm{mL}^{-1}$, dan pada $\mathrm{pH} 2$ jumlah koloni mencapai 1,3 $\times 10^{4}$

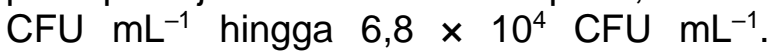
Viabilitas isolat BAL kombucha daun teh dan daun kopi robusta pada $\mathrm{pH} 3$ dan $\mathrm{pH} 2$ dapat dilihat pada Gambar 4. Di sini terlihat bahwa jumlah koloni pada $\mathrm{pH} 3$ dan $\mathrm{pH} 2$ mengalami penurunan apabila dibandingkan dengan $\mathrm{pH}$ kontrol. Jumlah koloni tertinggi pada $\mathrm{pH} 3$ dan $\mathrm{pH} 2$ ada pada isolat BAL kombucha daun kopi robusta $0,6 \%$.

Persentase ketahanan BAL meningkat pada $\mathrm{pH} 3$ dan $\mathrm{pH} 2$ seiring dengan peningkatan konsentrasi (Gambar 5). Persentase ketahanan tertinggi pada $\mathrm{pH}$ 3 dan $\mathrm{pH} 2$ ada pada kombucha daun kopi robusta $0,6 \%$. Secara keseluruhan, persentase ketahanan pada $\mathrm{pH} 3$ dan $\mathrm{pH} 2$ isolat BAL kombucha daun kopi robusta lebih tinggi dibandingkan dengan isolat BAL kombucha daun teh. Hal ini diduga disebabkan adanya perbedaan spesies dan strain BAL yang mempengaruhi kemampuan probiotik BAL (García-Ruiz et al. 2014). Perbedaan spesies dan strain BAL dapat dipengaruhi oleh kandungan fenol pada bahan baku kombucha yang digunakan. Pada analisa bahan baku (Tabel 1) ditunjukkan bahwa kandungan fenol pada seduhan daun teh lebih tinggi dibandingkan dengan seduhan daun kopi robusta. Menurut Sabel et al. (2017), beberapa jenis senyawa fenol mampu menghambat pertumbuhan BAL pada konsentrasi tertentu. Senyawa-senyawa fenol seperti asam sinamat, asam kafeat, asam ferulat, dan asam sinapat mampu menurunkan densitas sel BAL pada konsentrasi yang tinggi. Senyawa fenol memberikan pengaruh yang berbeda terhadap berbagai macam strain BAL. Lactobacilli mampu beradaptasi dengan baik terhadap asam galat, asam protokatekuat, asam vanilat, dan katekin. Katekin dan asam galat dapat mempercepat fase lag dan mempercepat pertumbuhan pada $L$. acidophilus dan $L$. rhamnosus. Namun asam protokatekuat, asam ferulat, dan asam vanilat dapat menghambat pertumbuhan L. acidophilus pada konsentrasi yang tinggi $\left(20-30 \mathrm{mmol}^{-}\right.$ $\left.{ }^{1}\right)$ (Palareti et al. 2016). Perbedaan strain dan spesies BAL yang ada pada kombucha daun teh dan kombucha daun kopi menyebabkan kemampuan probiotik BAL yang berbeda. 
BAL dapat bertahan pada kondisi asam diduga diakibatkan adanya aktivitas $\mathrm{F}_{0} \mathrm{~F}_{1-}$ ATPase yang mampu menjaga pergerakan proton melalui membran sel (Wang et al. 2016). Reaksi dekarboksilasi asam amino oleh BAL juga dapat menjaga homeostasis $\mathrm{pH}$ di dalam sel (Gänzle 2015). Membran BAL mengalami peningkatan rasio asam lemak tak jenuh akibat paparan asam sehingga $\mathrm{HCl}$ tidak dapat menembus membran sel (Puspawati dan Arihantana 2016). BAL juga dapat melakukan proses netralisasi melalui arginine dihydrolase system (ADS) dan fermentasi malolaktat dan menghasilkan karbon dioksida yang akan menetrasilasi proton di dalam sel (Wang et al. 2016).

Hasil analisa yang didapatkan didukung oleh penelitian yang dilakukan oleh Puspawati dan Arihantana (2016) yang menunjukkan adanya ketahanan 20 isolat BAL dari kombucha mampu bertahan pada kondisi lingkungan dengan $\mathrm{pH}$ 2. Penelitian yang dilakukan oleh Leite et al. (2015) juga menunjukkan bahwa terdapat 37 isolat BAL dari kefir Brazil yang diuji dapat bertahan hidup pada $\mathrm{pH} 3$.

\section{Ketahanan terhadap garam empedu}

Berdasarkan hasil yang didapatkan, jumlah koloni pada perlakuan garam empedu

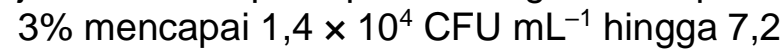

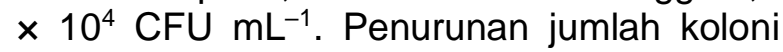
dan persentase ketahanan isolat BAL dapat dilihat pada Gambar 6 dan 7. Jumlah koloni pada garam empedu $3 \%$ mengalami penurunan apabila dibandingkan dengan kontrol. Jumlah koloni tertinggi pada garam empedu $3 \%$ ada pada isolat BAL kombucha daun kopi robusta $0,6 \%$. Gambar 7 menunjukkan bahwa persentase ketahanan isolat BAL pada kombucha daun teh 0,6 mengalami penurunan dibandingkan dengan konsentrasi sebelumnya, sedangkan persentase ketahanan BAL pada kombucha daun kopi robusta mengalami peningkatan seiring dengan peningkatan konsentrasi. Persentase ketahanan tertinggi ada pada kombucha daun kopi robusta $0,6 \%$. Secara keseluruhan, persentase ketahahan BAL pada isolat BAL kombucha daun kopi robusta lebih tinggi dibandingkan isolat BAL kombucha daun teh.

BAL dapat bertahan terhadap garam empedu diduga diakibatkan produksi bile salt hydrolase $(\mathrm{BSH})$ mengkatalisa hidrolisis garam empedu (Patel et al. 2010). BAL juga mengalami penurunan biosintesis asam lemak jenuh rantai panjang akibat paparan garam empedu sehingga garam empedu tidak dapat menembus membran sel (Koskenniemi et al. 2011). Menurut Bustos et al. (2011), paparan garam empedu menyebabkan terjadinya peningkatan 2 multidrug transcription untuk menghilangkan komponen garam empedu dari sel BAL.

Hasil analisa yang didapatkan didukung penelitian yang dilakukan oleh Puspawati dan Arihantana (2016) yang menunjukkan 12 isolat BAL dapat bertahan hidup terhadap garam empedu oxgall $0,5 \%$ setelah dilakukan inkubasi selama 4 jam. Penelitian yang dilakukan oleh Shehata et al. (2016) juga menunjukkan terdapat 9 isolat BAL yang diuji mampu bertahan terhadap garam empedu $0,3 \%$ setelah dilakukan inkubasi selama 3 jam.

\section{Aktivitas antibakteri}

Uji aktivitas antibakteri menggunakan 2 jenis bakteri yaitu $S$. aureus yang merupakan bakteri gram positif, dan E. coli yang merupakan bakteri gram negatif. Kedua jenis bakteri tersebut merupakan bakteri patogen yang banyak ditemukan pada makanan penyebab foodborne illness (Tan et al. 2014). Berdasarkan hasil yang didapatkan, diameter zona hambat isolat BAL kombucha daun teh dan daun kopi robusta pada bakteri $S$. aureus berkisar antara 2,17 hingga $4,50 \mathrm{~mm}$, sedangkan pada bakteri $E$. coli mencapai 3,83 hingga 6,50 $\mathrm{mm}$ (Gambar 8). Tampak di sini bahwa jenis daun dan konsentrasi memiliki diameter zona bening yang berbedabeda. Diameter zona hambat terbesar terhadap bakteri $E$. coli ada pada isolat BAL kombucha daun kopi robusta 0,2\%. Diameter zona hambat terbesar terhadap bakteri $S$. aureus ada pada isolat BAL kombucha daun teh $0,4 \%$. Secara keseluruhan, aktivitas antibakteri isolat BAL kombucha daun kopi robusta lebih efektif terhadap bakteri $E$. coli, sedangkan aktivitas antibakteri isolat BAL kombucha daun teh lebih efektif terhadap bakteri $S$. aureus.

Berdasarkan hasil yang didapat, secara keseluruhan aktivitas antibakteri isolat BAL kombucha daun teh dan daun kopi robusta lebih efektif terhadap Escherecia coli dibandingkan $S$. aureus. Hal ini diduga diakibatkan adanya asam laktat yang dapat 
menghancurkan lapisan lipopolisakarida sehingga senyawa antibakteri mampu menembus membran sel dan menyebabkan kematian sel (Cavicchioli et al. 2015).

Aktivitas antimikroba pada isolat BAL kombucha daun teh dan daun kopi robusta diakibatkan adanya kemampuan BAL memproduksi bakteriosin mengikat lipid II sehingga menghambat pembentukan dinding sel dan memicu kematian sel (Leite et al. 2015). Menurut Fujimura et al. (2012), BAL juga mampu menghasilkan senyawasenyawa asam organik dimana asam yang tidak terdisosiasi masuk ke dalam membran sitoplasma sehingga terjadi asidifikasi sitoplasma dan menyebabkan kegagalan pergerakan proton. Hasil samping dari fermentasi oleh BAL seperti hidrogen peroksida juga dapat menghambat pertumbuhan bakteri patogen dan bakteri psikotropis pada suhu dingin (Šušković et al. 2010).

Senyawa antimikroba bersifat bakteriosidal terhadap bakteri gram positif namun kurang efektif terhadap bakteri gram negatif. Hal ini disebabkan karena bakteri gram positif memiliki kerentanan yang tinggi akibat perbedaan struktur dinding sel, fisiologi sel, dan metabolisme derajat kontak (Ambrosio et al. 2017). Namun, berdasarkan hasil analisa dapat dilihat bahwa secara keseluruhan zona hambat isolat BAL kombucha daun teh dan daun kopi robusta pada bakteri E.coli lebih besar dibandingkan zona hambat pada $S$. aureus. Perbedaan ini diduga diakibatkan karena senyawa antibakteri yang dihasilkan oleh BAL mampu menembus membran sel bakteri gram negatif. Hasil ini didukung oleh Chen et al. (2020) yang menyatakan bahwa bakteri gram negatif memiliki membran terluar yang berfungsi sebagai pelindung dan memiliki lipopolisakarida sehingga dapat melindung sel dari berbagai macam senyawa antibakteri. Namun, membran terluar pada bakteri gram negatif dapat dirusak oleh senyawa permeabilizer seperti asam laktat yang dihasilkan oleh BAL. Asam laktat akan menghancurkan lapisan lipopolisakarida dan meningkatkan permeabilitas membran luar bakteri gram negatif. Hal ini menyebabkan senyawa antibakteri seperti bakteriosin dapat masuk ke dalam sitoplasma dan menyebabkan kematian sel (Wang et al. 2020).
Hasil analisa yang didapatkan didukung oleh penelitian yang dilakukan oleh Jeong et al. (2017) mengenai aktivitas antimikroba pada 2 isolat BAL pada produk probiotik komersial yang menunjukkan bahwa kedua isolat tersebut mampu menghambat pertumbuhan Salmonella enteritidis dan Listeria monocytogenes. Selain itu, penelitian Islam et al. (2020) mengenai aktivitas antimikroba isolat BAL yang didapatkan dari fermentasi mentimun dan wortel mampu menghambat pertumbuhan bakteri $S$. aureus, Bacillus sp, E. coli, dan S. tiphymurium.

\section{Isolat dengan potensi probiotik terbaik}

Pemilihan isolat BAL kombucha berbasis daun teh dan daun kopi robusta sebagai potensi probiotik terbaik dilakukan berdasarkan metode multiple attribute (Zeleny 1982). Parameter yang digunakan adalah ketahanan BAL pada $\mathrm{pH} 2$ dan $\mathrm{pH} 3$, ketahanan BAL pada garam empedu, aktivitas antibakteri terhadap $S$. aureus serta $E$. coli dengan nilai maksimal pada masingmasing parameter. Parameter tersebut merupakan beberapa syarat ideal mikroorganisme digolongkan sebagai probiotik (Tan et al. 2014). Berdasarkan metode multiple attribute, hasil yang didapatkan adalah isolat BAL kombucha berbasis daun kopi robusta dengan konsentrasi $0,6 \%$ memiliki kemampuan potensi probiotik terbaik apabila dibandingkan dengan sampel lainnya.

\section{KESIMPULAN}

Variasi jenis daun memberikan pengaruh yang nyata terhadap total asam kombucha selama proses fermentasi, sedangkan pada variasi konsentrasi daun tidak memberikan pengaruh nyata terhadap total asam kombucha. Isolat BAL dari kombucha berbasis daun teh dan daun kopi robusta dengan variasi konsentrasi $0,2 \%$, $0,4 \%$, dan $0,6 \%$ memiliki ketahanan terhadap $\mathrm{pH} 2, \mathrm{pH} 3$, dan garam empedu 3\% (b/v), serta aktivitas antibakteri terhadap bakteri $S$. aureus dan $E$. coli. Isolat BAL dengan potensi probiotik terbaik ada pada isolat BAL kombucha daun kopi robusta konsentrasi $0,6 \%$. Karakteristik berdasarkan parameter yang digunakan pada kombucha daun kopi robusta konsentrasi $0,6 \%$ antara lain persentase ketahanan isolat BAL terhadap 
pH 3 sebesar $67 \%$, persentase ketahanan isolat BAL terhadap $\mathrm{pH} 2$ sebesar $66 \%$, persentase ketahanan isolat BAL terhadap garam empedu 3\% (b/v) sebesar 69\%, aktivitas antimikroba terhadap $S$. aureus sebesar 3,67 mm, sedangkan aktivitas antimikroba terhadap E. coli sebesar 5,00 $\mathrm{mm}$.

\section{UCAPAN TERIMAKASIH}

Ucapan terimakasih kepada World Class University Kementrian Riset dan Teknologi Republik Indonesia (WCU Ristekdikti) yang telah memberikan dana untuk keberlangsungan penelitian ini.

\section{DAFTAR PUSTAKA}

Ambrosio CMS, de Alencar SM, de Sousa RLM, Moreno AM, Da Gloria EM (2017) Antimicrobial activity of several essential oils on pathogenic and beneficial bacteria. Ind Crop Prod 97: 128-136.

doi: 10.1016/j.indcrop.2016.11.045

Azka ABF, Santriadi MT, Kholis MN (2018) Pengaruh konsentrasi garam dan lama fermentasi terhadap sifat kimia dan organoleptik kimchi. Agroindustrial Technol J 2: 91-97. doi: 10.21111/atj.v2i1.2818

Bustos AY, Raya R, de Valdez GF, Taranto MP (2011) Efflux of bile acids in Lactobacillus reuteri is mediated by ATP. Biotechnol Lett 33: 2265-2269. doi: 10.1007/s10529-011-0696-3

Cavicchioli VQ, Dornellas W dos S, Perin LM, Pieri FA, Franco BD, Todorov SD, Nero LA (2015) Genetic diversity and some aspects of antimicrobial activity of lactic acid bacteria isolated from goat milk. Appl Biochem Biotechnol 175: 28062822. doi: $10.1007 / \mathrm{s} 12010-015-1511-8$

Chen L, Song Z, Tan SY, Zhang H, Yuk HG (2020) Application of bacteriocins produced from lactic acid bacteria for microbiological food safety. Curr Top Lact Acid Bact Probiotics 6: 1-8. doi: 10.35732/ctlabp.2020.6.1.1

Fibrianto K, Zubaidah E, Muliandari NA, Wahibah LY, Putri SD, Legowo A, AIBaarri AN (2020) Antioxidant activity optimisation of young Robusta coffee leaf kombucha by modifying fermentation time and withering pretreatment. IOP Conf Ser: Earth Environ Sci 475: 012029. doi: 10.1088/17551315/475/1/012029

Fujimura S, Watanabe A, Kimura K, Kaji M (2012) Probiotic mechanism of Lactobacillus gasseri OLL2716 strain against Helicobacter pylori. J Clin Microbiol 50: 1134-1136. doi: 10.1128/JCM.06262-11

Gänzle MG (2015) Lactic metabolism revisited: Metabolism of lactic acid bacteria in food fermentations and food spoilage. Curr Opin Food Sci 2: 106117. doi: 10.1016/j.cofs.2015.03.001

García-Ruiz A, González de Llano D, Esteban-Fernández $\mathrm{A}$, Requena $\mathrm{T}$, Bartolomé B, Moreno-Arribas MV (2014) Assessment of probiotic properties in lactic acid bacteria isolated from wine. Food Microbiol 44: 220-225. doi: 10.1016/j.fm.2014.06.015

Hrnjez D, Vaštag Z, Milanović S, Vukić V, Iličić M, Popović L, Kanurić K (2014) The biological activity of fermented dairy products obtained by kombucha and conventional starter cultures during storage. J Funct Foods 10: 336-345. doi: 10.1016/j.jff.2014.06.016

Islam R, Hossain MN, Alam MK, Uddin ME, Rony MH, Imran MAS, Alam MF (2020) Antibacterial activity of lactic acid bacteria and extraction of bacteriocin protein. Adv Biosci Biotechnol 11: 4959. doi: 10.4236/abb.2020.112004

Jeong D, Kim DH, Kang IB, Kim H, Song KY, Kim HS, Seo KH (2017) Characterization and antibacterial activity of a novel exopolysaccharide produced by Lactobacillus kefiranofaciens DN1 isolated from kefir. Food Control 78: 436-442. doi: 10.1016/j.foodcont.2017.02.033

König H, Unden G, Fröhlich J (2017) Biology of Microorganisms on Grapes, in Must and in Wine. Springer Int Pub,Switzerland. doi: 10.1007/978-3319-60021-5

Koskenniemi K, Laakso K, Koponen J, Kankainen M, Greco D, Auvinen P, Savijoki K, Nyman TA, Surakka A, Salusjärvi T, De Vos WM, Tynkkynen S, Kalkkinen N, Varmanen P (2011) Proteomics and transcriptomics characterization of bile stress response 
in probiotic Lactobacillus rhamnosus GG. Mol Cell Proteomics 10: 110.002741 . doi:

10.1074/mcp.M110.002741

Kumar M, Nagpal R, Kumar R, Hemalatha R, Verma V, Kumar A, Chakraborty C, Singh B, Marotta F, Jain S, Yadav H (2012) Cholesterol-lowering probiotics as potential biotherapeutics for metabolic diseases. Exp Diabetes Res 2012: $902917 . \quad$ doi: $10.1155 / 2012 / 902917$

Kusuma GSP, Fibrianto K (2018) Pengaruh optimasi lama fermentasi terhadap karakteristik kombucha daun tua kopi robusta Dampit metode oksidatif dan non-oksidatif. J Pangan Agroindustri 6: 87-97. doi: 10.21776/ub.jpa.2018.006.04.10

Laureys D, Britton SJ, De Clippeleer J (2020) Kombucha tea fermentation: A review. J Am Soc Brew Chem 78: 165-174. doi: 10.1080/03610470.2020.1734150

Leite AMO, Miguel MAL, Peixoto RS, RuasMadiedo P, Paschoalin VMF, Mayo B, Delgado $S$ (2015) Probiotic potential of selected lactic acid bacteria strains isolated from Brazilian kefir grains. $J$ Dairy Sci 98: 3622-3632. doi: 10.3168/jds.2014-9265

Noriko N (2013) Potensi daun teh (Camellia sinensis) dan daun anting-anting Acalypha indica L. dalam menghambat pertumbuhan Salmonella typhi. J AlAzhar Indones Ser Sains Teknol 2: 104110. doi: 10.36722/sst.v2i2.131

Novita R, Kasim A, Anggraini T, Putra DP (2018) Kahwa daun: traditional knowledge of a coffee leaf herbal tea from West Sumatera, Indonesia. J Ethnic Foods 5: 286-291. doi: 10.1016/j.jef.2018.11.005

Nur YM, Indrayati S, Periadnadi, Nurmiati (2018) Pengaruh penggunaan beberapa jenis ekstrak tanaman beralkaloid terhadap produk teh kombucha. J Biol Univ Andalas 6: 5562. doi: 10.25077/jbioua.6.1.5562.2018

Palareti G, Legnani C, Cosmi B, Antonucci E, Erba N, Poli D, Testa S, Tosetto A (2016) Comparison between different D-Dimer cutoff values to assess the individual risk of recurrent venous thromboembolism: Analysis of results obtained in the DULCIS study. Int J Lab Hem 38: 42-49. doi: 10.1111/ijlh.12426

Patel AK, Singhania RR, Pandey A, Chincholkar SB (2010) Probiotic bile salt hydrolase: Current developments and perspectives. Appl Biochem Biotechnol 162: 166-180. doi: 10.1007/s12010-009-8738-1

Pinto L, Malfeito-Ferreira M, Quintieri L, Silva AC, Baruzzi F (2019) Growth and metabolite production of a grape sour rot yeast-bacterium consortium on different carbon sources. Int $\mathrm{J}$ Food Microbiol 296: 65-74. doi: 10.1016/j.ijfoodmicro.2019.02.022

Puspawati NN, Arihantana NMIH (2016) Viability of lactic acid bacteria isolated from kombucha tea against low $\mathrm{pH}$ and bile salt ketahanan bakteri asam laktat yang diisolasi dari teh kombucha terhadap $\mathrm{pH}$ rendah dan garam empedu. Media Ilmiah Teknologi Pangan 3(1): 18-25

Sabel A, Bredefeld S, Schlander M, Claus H (2017) Wine phenolic compounds: Antimicrobial properties against yeasts, lactic acid and acetic acid bacteria. Beverages 3: 29 . doi: 10.3390/beverages3030029

Saguibo JD, Mercado MA, Maldia ST, Jimeno BT, Perez MTM, Calapardo MR, Elegado FB (2019) Identification and characterization of lactic acid bacteria isolated from some medicinal and/or edible Philippine plants. Food Res 3: 698-712. doi: 10.26656/fr.2017.3(6).148

Sengun IY, Kirmizigul A (2020) Probiotic potential of kombucha. J Functional Foods 2020: 104284. doi: 10.1016/j.jf.2020.104284

Shang YF, Cao H, Ma YL, Zhang C, Ma F, Wang $\mathrm{CX}$, Ni XL, Lee WJ, Wei ZJ (2019) Effect of lactic acid bacteria fermentation on tannins removal in Xuan Mugua fruits. Food Chem 274: 118-122. doi: 10.1016/j.foodchem.2018.08.120

Shehata MG, EI Sohaimy SA, EI-Sahn MA, Youssef MM (2016) Screening of isolated potential probiotic lactic acid bacteria for cholesterol lowering property and bile salt hydrolase activity. Ann Agric Sci 61: 65-75. doi: 10.1016/j.aoas.2016.03.001 
Sudarmaji S, Haryono B (1997) Prosedur Analisa Bahan Makanan dan Pertanian. Liberty, Yogyakarta

Šušković J, Kos B, Beganović J, Pavunc AL, Habjanič K, Matoć S (2010) Antimicrobial activity - The most important property of probiotic and starter lactic acid bacteria. Food Technol Biotechnol 48: 296-307

Tan SL, Lee HY, Mahyudin NA (2014) Antimicrobial resistance of Escherichia coli and Staphylococcus aureus isolated from food handler's hands. Food Control 44: 203-207. doi: 10.1016/j.foodcont.2014.04.008

Villarreal-Soto SA, Beaufort S, Bouajila J, Souchard JP, Taillandier P (2018) Understanding kombucha tea fermentation: A review. J Food Sci 83: 580-588. doi: 10.1111/17503841.14068

Wang M, Gao Z, Zhang Y, Pan L (2016) Lactic acid bacteria as mucosal delivery vehicles: A realistic therapeutic option. Appl Microbiol Biotechnol 100: 5691-5701. doi: 10.1007/s00253-016-7557-x

Wang Y, Wang J, Bai D, Wei Y, Sun J, Luo Y, Zhao J, Liu Y, Wang Q (2020) Synergistic inhibition mechanism of pediocin PA-1 and L-lactic acid against Aeromonas hydrophila. Biochim Biophys Acta Biomembr 1862: 183346. doi: 10.1016/j.bbamem.2020.183346

Zeleny M (1982) Multiple Criteria Decision Making. McGraw Hill, New York 